Original Research Paper

\title{
The Effect of Lemongrass Stem (Cymbopogon citratus) and Salam Leaves (Syzygium polyanthum) Ethanol Extracts on The Number of Bactrocera Fruit Flies Catches
}

\author{
Yunisa Sucitra $^{1}$, Syamsul Bahri $^{{ }^{*}}$, I Putu Artayasa ${ }^{1}$ \\ ${ }^{1}$ Program Studi Pendidikan Biologi, Fakultas Keguruan dan Ilmu Pendidikan, Universitas Mataram, \\ Mataram, Indonesia
}

\author{
Article History \\ Received : December $14^{\text {th }}, 2021$ \\ Revised : December 29 , 2021 \\ Accepted : January $19^{\text {th }}, 2022$ \\ Published : January $28^{\text {th }}, 2022$ \\ *Corresponding Author: \\ Syamsul Bahri, \\ Program Studi Pendidikan \\ Biologi, Fakultas Keguruan dan \\ Ilmu Pendidikan, Universitas \\ Mataram, Mataram, Indonesia; \\ Email: syamsulsalihu@gmail.com
}

\begin{abstract}
Bactrocera fruit fly (Diptera: Tephritidae) is one of the important pests in horticulture which is very detrimental. Lemongrass stems and salam leaves are be able used as vegetable attractants in controlling fruit fly pests. This study aimed to determine the effect of lemongrass (Cymbopogon citratus) and salam leaves (Syzygium polyanthum) ethanol extract and their mixtures on the number of catches of Bactrocera fruit flies and to determine the effect of the concentration of lemongrass (Cymbopogon citratus) and salam leaves (Syzygium polyanthum) ethanol extract and their mixtures on the number of catches of Bactrocera sp. The experimental design used in this research was a Randomized Block Design (RBD). The collected data were analyzed by $\mathrm{F}$ test two-way analysis at $95 \%$ significance level, followed by Honest Significant Difference Test (HSD) at 95\% significance level. The results showed that the use of traps containing ethanol extracts of lemongrass stems and salam leaves and a mixture of the two had succeeded in catching two strains of fruit flies, namely Bactrocera albistrigata (97 individuals) and Bactrocera carambolae (32 individuals), while traps without these extracts failed to catch Bactrocera fruit flies. It is concluded the treatment of lemongrass stems (Cymbopogon citratus) and salam leaves (Syzygium polyanthum) ethanol extract, and their mixtures significantly effect on the number of Bactrocera fruit fly catches, while the treatment with different ethanol extract concentrations of $35 \%, 45 \%$, and $55 \%$ has no significantly effect on the number of Bactrocera fruit fly catches.
\end{abstract}

Keywords: Attractants, Fruit Fly, Lemongrass Stem (Cymbopogon citratus), Salam Leaves (Syzygium polyanthum).

\section{Pendahuluan}

Indonesia adalah negara tropis dengan SDA hayati dengan tingkat keanekaragaman yang tinggi. Curah hujan tinggi memungkinkan banyak jenis tumbuhan, terutama buah-buahan ditemukan tumbuh melimpah di pelosok wilayah Indonesia (Aulani et al., 2013). Sektor hortikultura merupakan sektor pertanian yang pesat perkembangannya dengan prospek yang menjanjikan (Sari et al., 2020). Komoditas yang termasuk holtikultura adalah tanaman buah dan sayur-sayuran yang kandungan gizinya menjadi sumber vitamin serta mineral (Budiyani \& Sukasana, 2020). Meskipun demikian produksi buah-buahan ini dapat terganggu oleh organisme tertentu seperti lalat buah (Kardinan et al., 2009). Pada bidang hortikultura, organisme hama yang menjadi faktor pembatas perdagangan adalah lalat buah Bactrocera sp. Organisme ini telah tersebar hampir seluruh negara (Huan et al., 2018). Kerugian yang ditimbulkan oleh organisme ini bisa bersifat kuantitatif karena berkurangnya hasil panen dan/atau kualitatif karena berkurangnya kualitas hasil panen. Kehadiran serangga hama pada buah yang masih muda membuat buah rontok. Bila hama ini menginfeksi buah yang telah tua membuat buah membusuk dan dipenuhi dengan belatung.

Di Indonesia, genus Bactrocera adalah spesies yang ditemunkan paling dominan merusak tanaman buah. Genus ini tergolong ke dalam 
famili Tephritidae. Oleh karena itu famili Tephritidae menduduki posisi yang penting dari segi ekonomi karena sangat merugikan (Siwi et al., 2006). Jenis buah yang telah diketahui dapat diinfeksi oleh hama ini lebih 20 spesies. Alpukat dan jambu-jambuan adalah contoh spesies tanaman inangnya (Muryati et al., 2007).

Menurut Kardinan (2003), metil eugenol $\left(\mathrm{C}_{12} \mathrm{H}_{24} \mathrm{O}_{2}\right)$ adalah atraktan yang efektif digunakan dalam pengendalian lalat buah. Disamping ramah lingkungan karena tidak beracun, atraktan ini juga tidak menyisakan residu. Dari sisi biaya, penggunaan metil eugenol juga dianggap lebih ekonomis. Disamping itu bahan aktif ini gampang dipakai dalam radius yang luas karena bahannya mudah menguap. Lokasi, cuaca, komoditas, dan keadaan buah di lapangan menentukan daya tangkap atraktan ini (Kardinan, 2019).

Beberapa jenis tanaman telah diketahui mengandung atraktan alami berupa metil eugenol dan eugenol. Eugenol misalnya, berupa cairan bening sampai kuning pucat dengan bau khas tanaman sumbernya (Kardinan, 2005). Menurut Simbolon et al. (2015). daun salam (Syzygium polyanthum) adalah salah satu tumbuhan yang mengandung eugenol. Menurut Kardinan (2011) metil eugenol terdapat pada beberapa tanaman. Metil eugenol juga terkandung dalam minyak atsiri serai (Ladja et al., 2018). Dengan demikian efek senyawa atraktan yang terdapat dalam ekstrak batang serai (Cymbopogon citratus) maupun senyawa atraktan yang terdapat dalam daun salam (Syzygium polyanthum) terhadap jumlah Bactrocera sp. yang tertangkap dalam upaya mengendalikan lalat buah (Diptera: Tephritidae) sangat menarik untuk diteliti.

\section{Bahan dan Metode}

\section{Waktu dan Tempat Penelitian}

Penelitian ini dilakukan pada Agustus September 2021 di Kebun Agrowisata Buah Mas Ari yang terletak di Jl. Jendral Sudirman Kelurahan Karang Baru, Kota Mataram. Tempat pengambilan data penelitian tersebut ditunjukkan pada Gambar 1.

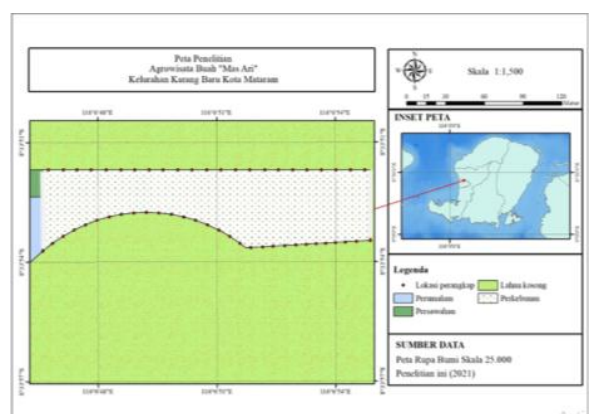

Gambar 1. Peta Lokasi Penelitian

Pada penelitian ini digunakan Rancangan Acak Kelompok (RAK) dua faktor. Ada 9 kombinasi dan 3 kontrol. Setiap kombinasi perlakuan menggunakan 3 perangkap yang ditempatkan dalam 3 kelompok yang berbeda sehingga 1 kombinasi perlakuan menggunakan perangkap. Faktor pertama berupa jenis ekstrak tumbuhan yang digunakan sebagai sumber senyawa atraktan, yakni:

$\mathrm{K}=$ air

SE $\quad=$ Ekstrak batang serai.

SA $=$ Ekstrak daun salam.

$\mathrm{C}=$ Campuran ekstrak batang serai dengan ekstrak daun salam.

Ada 3 konsentrasi ekstrak yang diuji yaitu: $35 \%, 45 \%$, dan 55\%. Pengambilan data dilakukan sebanyak 9 kali.

\section{Pembuatan Perangkap}

Desain perangkap lalat buah dibuat menurut Lestari et al. (2020). Bahan yang digunakan berupa wadah plastik air minum volume 1,5 liter. Bagian atas kemasan yang telah dipotong melintang kemudian dipasang kembali dengan posisi terbalik sehingga mulut kemasan menempel pada bekas potongan sebelmunya. Pada kedua ujung wadah diikatkan tali raffia sehingga wadah bisa digantung. Setelah itu bagian tengah wadah dilubangi. Lubang tersebut menjadi tempat lewatnya kawat tempat kapas yang mengandung atraktan terkait.

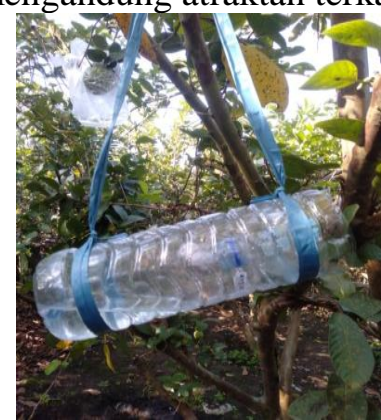

Gambar 2. Perangkap Lalat Buah 


\section{Pembuatan ekstrak}

Batang serai dan daun salam yang telah dibersihkan dengan air dicacah kemudian dikering anginkan. Setelah kering kedua bahan uji ini kemudian dihaluskan menggunakan blender. Hasil dari proses penghalusan ditimbang masing-masing 250 gr dan dimaserasi menggunakan $1000 \mathrm{ml}$ alkohol 96\% selama 5 hari. Untuk memisahkan pelarut dan zat-zat terlarut dengan bahan-bahan sisa lainnya dilakukan penyaringan dengan kertas saring. Larutan yang tersaring lalu diuapkan dengan evaporator bersuhu $70^{\circ} \mathrm{C}$ sehingga didapatkan ekstrak etanol. Pengenceran dilakukan untuk mendapatkan konsentrasi yang diinginkan yakni $35 \%, 45 \%$, dan $55 \%$.

\section{Pemberian Perlakuan pada Perangkap}

Perangkap pertama menggunakan sepuluh tetes atraktan yang diekstrak dari batang serai dengan konsentrasi 35\%, 45\%, dan 55\%. Perangkap kedua juga menggunakan sepuluh tetes atraktan yang diekstrak dari daun salam dengan konsentrasi $35 \%$, 45\%, dan 55\%, sedangkan perangkap ketiga menggunakan sepuluh tetes atraktan yang diekstrak dari batang serai dengan konsentrasi 35\%, 45\%, dan 55\% yang dicampur dengan 10 tetes atraktan yang diekstrak dari daun salam dengan konsentrasi $35 \%$, 45\%, dan 55\%. Atraktan dengan berbgai konsentrasi ini masing-masing diteteskan pada kapas kemudian dikaitkan pada pada ujung kawat, lalu dimasukkan ke dalam masing-masing perangkap. Sebagai kontrol digunakan perangkap yang kapasnya hanya ditetesi dengan air saja. Dengan demikian, total perangkap berjumlah 36 buah.

\section{Peletakan Perangkap}

Perangkap diletakkan pada pohon-pohon buah yang terletak di pinggir Kebun Agrowisata Buah Mas Ari. Jarak perangkap dari tanah sekitar 100 - 150 centi meter, sedangkan jarak antar perangkap sekitar 1000 centi meter. Perangkap dipasang sekitar jam 08.00 pagi. Pemeriksaan perangkap dan penghitungan jumlah tangkapan pada masing-masing perangkap dilakukan setelah terpasang selama 3 X 24 jam. Kebun Agrowisata Buah Mas Ari yang terletak di Jl. Jendral Sudirman Kelurahan Karang Baru, Kota Mataram yang menjadi lokasi penelitian, memiliki luas 1 hektar. Pengambilan data dilakukan sebanyak 9 kali ulangan. Pada setiap ulangan posisi perangkap dirubah secara random sederhana. Disamping itu diteteskan pula atraktan baru pada setiap ulangan.

\section{Identifikasi Lalat Buah}

Setelah dilakukan penghitungan, lalat buah tersebut diamati dengan mikroskop bedah untuk menentukan spesiesnya. Proses identifikasi dilakukan dengan mikroskop bedah di Lab Biologi FKIP UNRAM. Identifikasi spesies lalat buah ini mengacu pada petunjuk dari Buku Plant Health Australia (2018) dan Buku Taksonomi dan Bioekologi Lalat Buah Penting di Indonesia (Siwi et al., 2006).

\section{Analisis Data}

Analisis data memakai uji $\mathrm{F}$ dua arah dengan tingkat signifikansi 95\% dengan bantuan SPSS 16, yang dilanjutkan Uji BNJ dengan tingkat signifikansi $95 \%$.

\section{Hasil dan Pembahasan}

\section{Jenis Lalat Buah}

Penelitian yang telah dilakukan di Kebun Agrowisata Buah Mas Ari pada bulan Agustus sampai September 2021 ditemukan 2 spesies Bactrocera, yakni $B$. albistrigata dan $B$. carambolae. Semua Bactrocera yang masuk perangkap merupakan Bactrocera jantan.
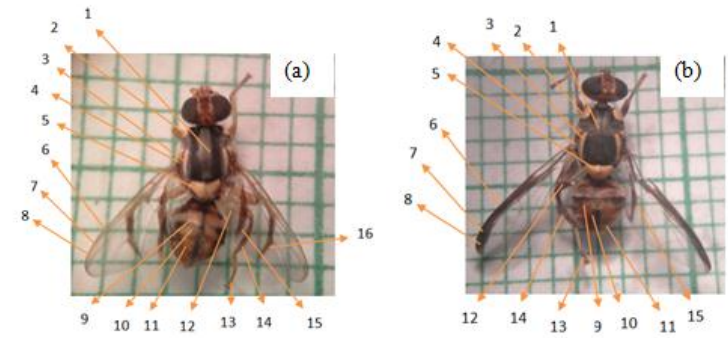

Gambar 3. (a) Bactrocera albistrigata (Jantan) dan (b) Bactrocera carambolae (Jantan)

$$
\begin{array}{lrl}
\text { Keterangan: } & \\
1=\text { Skutum } & 9=\text { Terga III } \\
2=\text { Lobus postprontal } & 10=\text { Terga IV } \\
3=\text { Vittae lateral } & 11=\text { Terga V } \\
4=\text { Setae posterior } & 12=\text { Femur } \\
5=\text { Skutellum } & 13=\text { Tarsi } \\
6=\text { R } 2+3 & 14=\text { Tibia } \\
7=\text { Pita costal } & 15=\text { Garis anal } \\
8=\text { R4+5 } & 16=\text { Pita melintang }
\end{array}
$$


Ciri morfologi B. albistrigata, yakni tubuh dominan berwarna hitam dengan spot pada kepala. Pada bagian tepi skutum ditemukan garis lateral berwarna kuning. Pada bagian tengah skutum terdapat garis longitudinal keputihan. Lobus postpronotal berwarna kuning. Sayap dengan pita costal yang sangat tipis dengan pita coklat kehitaman melintang melewati r-m dan dm-cu dan terdapat pita hitam pada garis anal. Daerah persebaran lalat buah ini ada di Jawa, Lombok, Sulawesi, Sumatera, dan Papua (Siwi et al., 2006). Tumbuhan inang B. albistrigata yakni jejambuan dan nangka. Lalat buah jenis ini juga berpotensi menjadi hama tumbuhan Syzygium spp. atau kelompok tanaman Myrtacea (Drew \& Hancock 1994).

Ciri morfologi B. carambolae yakni skutum hitam. Pada bagian tepi struktur ini ditemukan pita kuning. Bagian lobus post pronotal kuning. Pada bagian sayapnya ditemukan pita berwarna hitam pada garis costa dan garis anal. Pola sayap pada bagian ujung mirip kail. Abdomen dengan pola $\mathrm{T}$ yang jelas dan terdapat pola hitam dengan bentuk segiempat pada tergum IV. Daerah persebaran lalat buah ini ada di Pulau Jawa, Pulau Lombok, Pulau Sumbawa bagian timur, serta Pulau Kalimantan (Siwi et al., 2006). Tumbuhan yang menjadi inang B. carambolae yaitu belimbing dan banyak juga yang menyerang jambu air (White \& Hancock, 1997).

Pada hasil penelitian ini dditemukan bahwa B. albistrigata yang tertangkap jumlahnya lebih banyak dari B. carambolae (Jantan). Total B. albistrigata yang tertangkap berjumlah 97 individu, sementara jumlah keseluruhan $B$. carambolae tertangkap sebanyak 32 individu. Penelitian yang dilakukan oleh Lestari (2020) lalat buah yang diperoleh, yaitu Bactrocera carambolae 623 individu, Bactrocera dorsalis 603 individu, dan B. umbrosa 72 individu, sedangkan lalat buah $B$. albistrigata tidak tertangkap. Hal ini disebabkan oleh perbedaan kondisi lingkungan dan ketersediaan tanaman inang pada lokasi penelitian.

Lebih banyaknya jumlah individu $B$. albistrigata yang terperangkap diduga disebakan oleh jumlah tumbuhan inang $B$. albistrigata yang ditanam pada area penelitian lebih banyak. Banyak faktor yang menyebabkan tanaman inang potensial terserang Bactrocera. Faktor-faktor tersebut antara lain kematangan buah, bentuk buah, dan warna buah, serta tekstur buah (Siregar \& Sutikno, 2015). Tanaman inang lalat buah Bactrocera albistrigata adalah jambu biji, jambu air, jambu bol, dan nangka (Drew \& Hancock, 1994), sedangkan tanaman inang B. carambolae yaitu belimbing dan banyak juga yang menyerang jambu air (White \& Hancock, 1997). Pada lokasi penelitian yaitu Kebun Agrowisata Buah Mas Ari memang ditumbuhi sejumlah tanaman seperti jambu air, jambu kristal, jambu bangkok, belimbing, jeruk, kelengkeng, dan pepaya. Kondisi lokasi penelitian ini lah yang menyebabkan sehingga Bactrocera albistrigata lebih banyak yang terperangkap.

\section{Pengaruh Ekstrak Terhadap Jumlah Tangkapan Lalat Buah}

Ketertarikan Bactrocera terhadap perangkap disebabkan oleh adanya aroma atraktan yang tercium oleh lalat buah. Metil eugenol adalah salah satu jenis atraktan yang banyak dipakai untuk menangkap Bactrocera Metil eugenol berfungsi untuk menarik atau mengumpan serangga (Kardinan, 2005). Aroma atraktan serupa dengan aroma yang dihasilkan lalat buah betina sehingga senyawa ini berperan sebagai paraferomon yang hanya mampu memikat laat buah jantan (Aulani et al., 2013). Atraktan yang diuji pada penelitian ini yaitu atraktan dari tanaman, yaitu batang serai (Cymbopogon citratus) dan daun salam (Syzygium polyanthum).

Data tentang jumlah tangkapan lalat buah seperti yang tersaji pada gambar 4 memperlihatkan bahwa jumlah tangkapan terbanyak ditemukan pada perangkap yang menggunakan ekstrak batang serai yaitu 52 inividu, diikuti dengan campuran ekstrak batang serai dan daun salam sebanyak 43 individu dan ekstrak daun salam sebanyak 34 individu. Tidak ditemukan tangkapan pada kelompok kontrol. Data tentang pengaruh konsentrasi ekstrak terhadap jumlah tangkapan seperti yang tersaji pada gambar 5 memperlihatkan jumlah tangkapan terbesar yaitu 20 individu ditemukan pada perangkap yang menggunakan ekstrak batang serai konsentrasi 55\%, sementara jumlah tangkapan terkecil ditemukan pada perangkap yang menggunakan ekstrak daun salam dengan konsentrasi 35\%, yaitu 10 individu. Data tentang rerata jumlah tangkapan pada perangkap yang menggunakan ekstrak Cymbopogon citratus dan 
ekstrak Syzygium polyanthum serta campurannya tersaji dalam gambar 6 .

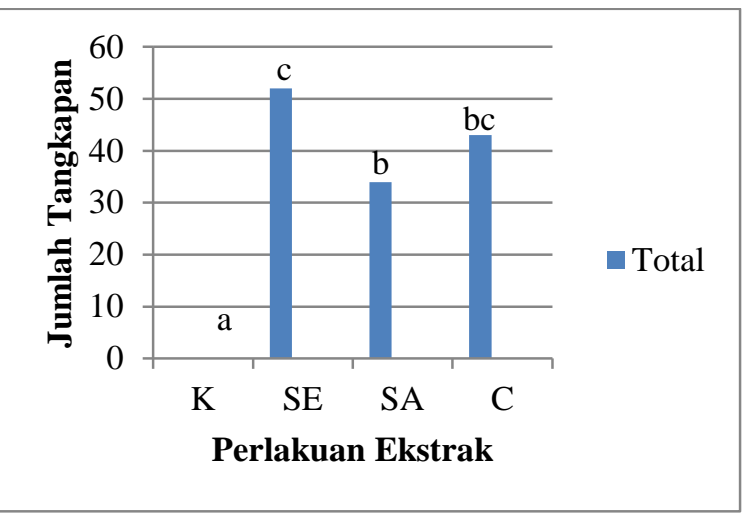

Gambar 4. Pengaruh jenis ekstrak terhadap jumlah tangkapan lalat buah

Keterangan:

$\mathrm{K}=$ air

$\mathrm{SE} \quad=$ Ekstrak batang serai.

SA $=$ Ekstrak daun salam.

$\mathrm{C}=$ Campuran ekstrak batang serai dengan ekstrak daun salam.

Notasi yang berbeda pada puncak batang, berbeda nyata dalam Uji BNJ 95\%.

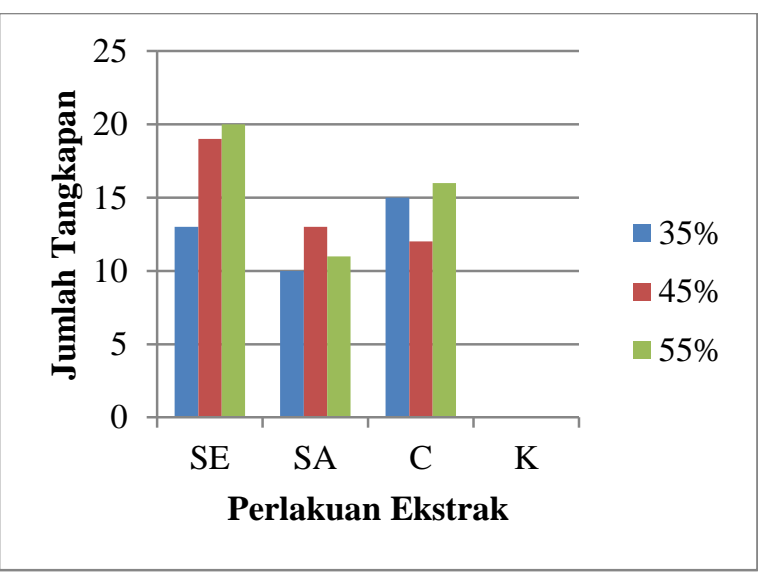

Gambar 5. Pengaruh konsentrasi ekstrak terhadap jumlah tangkapan lalat buah

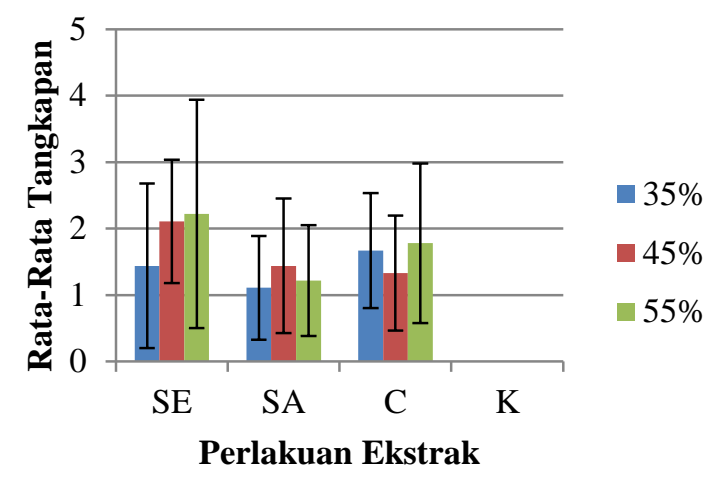

Gambar 6. Rerata jumlah Bactrocera yang terperangkap pada ekstrak batang serai (SE) dan daun salam (SA) dengan konsentrasi yang berbeda

Analisis statistik menggunakan Uji F dua arah yang dilakukan pada program SPSS 16. Hasil Ui F disajikan pada tabel 1 . Karena nilai signifikansi ekstrak sebesar 0,035 lebih kecil dari 0,05 maka jenis ekstrak berpengaruh nyata terhadap jumlah tangkapan, sedangkan nilai signifikansi konsentrasi 0,411>0,05 yang berarti bahwa konsentrasi ekstrak yang diuji pada penelitian ini tidak memberi pengaruh nyata pada jumlah Bactrocera yang terperangkap. Demikian pula halnya dengan interaksi ekstrak dengan konsentrasi juga tidak berpengaruh nyata jumlah Bactrocera yang terperangkap, karena nilai signifikansi hanya 0,468 . Nilai tersebut lebih besar dari 0,05 .

Uji lanjut dengan menggunakan Uji BNJ seperti yang tersaji pada tabel 2 menunjukkan bahwa seluruh perlakuan memberi pengaruh nyata dibandingkan dengan kontrol. Perlakuan dengan jumlah tangkapan terbaik adalah perangkap yang menggunakan ekstrak batang serai yang berbeda nyata dengan jumlah tangkapan pada perangkap yang menggunakan ekstrak daun salam. Meskipun demikian perlakuan dengan esktrak batang serai tidak berbeda nyata dengan jumlah tangkapan yang diperoleh dari perangkap yang menggunakan campuran ektrak batang serai dengan ekstrak daun salam.

Lebih tingginya jumlah tangkapan pada perangkap yang menggunakan ekstrak batang serai dibandingkan dengan perangkap yang menggunakan ekstrak daun salam kemungkinan dipengaruhi oleh tingginya konsentrasi atraktan yang terkandung di dalam ekstrak batang serai. 
Menurut Wardani (2009) kandungan metil eugenol pada serai mencapai $32-45 \%$.

Menurut Hasyim et al. (2020) lalat buah bisa hidup dan berkembang biak dengan rentang suhu $10^{\circ} \mathrm{C}-30^{\circ} \mathrm{C}$ dengan kelembaban optimum $70 \%-80 \%$. Rerata suhu pada lokasi penelitian yaitu $27,9^{\circ} \mathrm{C}$ dengan kelembaban rata-rata $63,7 \%$. Oleh karena nilai faktor-faktor fisik di lokasi penelitian masih bearada pada rentang suhu dan kelembaban tersebut maka suhu dan kelembaban tampaknya tidak berpengaruh terhadap tinggi rendahnya jumlah hasil tangkapan lalat buah. Menurut Susanto et al. (2018) faktor iklim seperti suhu, jumlah curah hujan, dan hari hujan tidak berkorelasi nyata dengan jumlah tangkapan lalat buah. Dengan demikian jumlah tangkapan tampaknya lebih ditentukan oleh faktor lain seperti faktor ketersediaan inang. Jumlah buah serta tingkat kematangannya yang tidak seragam pada lokasi penelitian juga dapat mempengaruhi jumlah tangkapan lalat buah.

Tabel 1. Ui F pengaruh ekstrak batang serai dan daun salam terhadap jumlah tangkapan lalat buah

Tests of Between-Subjects Effects

Dependent Variable:Jumlah_Tangkapan_Lalat_Buah

\begin{tabular}{|c|c|c|c|c|c|}
\hline Source & $\begin{array}{c}\text { Type III Sum of } \\
\text { Squares }\end{array}$ & df & Mean Square & $\mathrm{F}$ & Sig. \\
\hline Corrected Model & $62.028^{a}$ & 9 & 6.892 & 7.956 & .000 \\
\hline Intercept & 170.969 & 1 & 170.969 & 197.375 & .000 \\
\hline Ekstrak & 6.000 & 2 & 3.000 & 3.463 & .035 \\
\hline Konsentrasi & 1.556 & 2 & .778 & .898 & .411 \\
\hline Ekstrak * Konsentrasi & 3.111 & 4 & .778 & .898 & .468 \\
\hline Error & 84.889 & 98 & .866 & & \\
\hline Total & 301.000 & 108 & & & \\
\hline Corrected Total & 146.917 & 107 & & & \\
\hline
\end{tabular}

a. R Squared = ,422 (Adjusted R Squared = ,369)

Tabel 2. Rerata tangkapan lalat buah (Bactrocera sp.) berdasarkan perbedaan ekstrak

\begin{tabular}{cccccccccccc}
\hline \multirow{2}{*}{ Ekstrak } & $\mathrm{N}$ & \multicolumn{8}{c}{ Tangkapan Lalat Buah } & \multirow{2}{*}{ Rata-rata } \\
\cline { 3 - 9 } & & $\mathrm{U} 1$ & $\mathrm{U} 2$ & $\mathrm{U} 3$ & $\mathrm{U} 4$ & $\mathrm{U} 5$ & $\mathrm{U} 6$ & $\mathrm{U} 7$ & $\mathrm{U} 8$ & $\mathrm{U} 9$ & \\
\hline Kontrol & 27 & 0 & 0 & 0 & 0 & 0 & 0 & 0 & 0 & 0 & $0,0000^{\mathrm{a}}$ \\
$\begin{array}{c}\text { Daun salam } \\
\text { Batang serai } \\
\text { dan daun }\end{array}$ & 27 & 0 & 2 & 3 & 5 & 5 & 6 & 4 & 5 & 4 & $1,2593^{\mathrm{b}}$ \\
$\begin{array}{c}\text { salam } \\
\text { Batang serai }\end{array}$ & 27 & 1 & 1 & 3 & 5 & 5 & 7 & 6 & 7 & 8 & $1,5926^{\mathrm{bc}}$ \\
\hline
\end{tabular}

Keterangan: Angka yang diikuti dengan notasi yang sama tidak berbeda secara signifikan pada Uji BNJ taraf signifikansi $95 \%$

Ada beberapa jenis minyak atsiri yang terkandung dalam serai, diantaranya adalah metil heptenol, dan dipentena (Guenther 1990; Herminanto et al., 2010). Di dalam jaringan tanaman serai terkandung senyawasenyawa metabolit sekunder berupa saponin, flavonoid, dan polifenol, dan persentase terbanyak yaitu sitronela sebesar 35\% dan graniol sebanyak 35\% hingga 40\%. (Saenong, 2016).
Menurut Giri (2008) ada beberapa senyawa kimia yang terkandung di dalam daun salam diantaranya saponin dan triterpenoid. Jenis minyak atsiri yang terkandung didalamnya adalah sesquiterpen, lakton, dan fenol. Kandungan minyak essensial pada daun salam mencapai $17 \%$. Senyawa ini didominasi eugenol dan methyl chavicol (de Guzman \& Simeosma, 1999). Asam sitrat juga ditemukan ikut 
menyusun minyak esensial dalam daun salam (Sumono \& Agustin, 2008). Masa aktif atraktan berbanding lurus dengan konsentrasi eugenol atau metil eugenol yang terdapat dalam ekstrak tanaman (Effendy et al. 2010).

Jumlah tangkapan pada perangkap yang menggunakan campuran ekstrak batang serai dengan ekstrak lebih rendah dibandingkan dengan jumlah tangkapan pada perangkap yang hanya menggunakan ektrak batang serai. Hal tersebut berarti bahwa ektrak daun salam salam bersifat menurunkan daya pikat atraktan ekstrak batang serai. Menurut Kardinan (2007) pencampuran bahan kimia bisa bersifat sinergis ataupun antagonis.

Berdasarkan hasil Uji F ditemukan bahwa konsentrasi ekstrak tidak mempengaruhi pada jumlah Bactrocera yang terperangkap. Hal ini berarti bahwa konsentrasi ekstrak 35\%, 45\%, dan $55 \%$ memiliki potensi yang sama sebagai pemikat lalat buah. Meskipun tidak signifikan, konsentrasi ekstrak 55\% rerata tangkapannya paling banyak. Fenomena ini sesuai dengan hasil penelitian Lestari et al. (2020) yang juga menemukan bahwa konsentrasi tertinggi memiliki rerata tangkapan yang juga tertinggi. Hal ini tampaknya terkait dengan konsentrasi metil eugenol di dalam ekstraknya (Efendy et al., 2010).

\section{Kesimpulan}

Ekstrak etanol batang serai (Cymbopogon citratus), ekstrak etanol daun salam (Syzygium polyanthum) serta campurannya mempengaruhi jumlah tangkapan Bactrocera sp.

\section{Ucapan terima kasih}

Terima kasih kami haturkan kepada Bapak Ariyanto atas perkenaannya dalam penggunaan Kebun Agrowisata Buah Mas Ari miliknya sebagai lokasi penelitian.

\section{Referensi}

Aulani, F., Artayasa, I P., \& Ilhamdi, M. L. (2013). Pengaruh Minyak Kayu Putih (Melaleuca leucadendron L.) dan Minyak Serei (Cymbopogon nardus L.) Serta Campurannya Terhadap Tangkapan Lalat Buah Bactrocera. Jurnal Biologi Tropis,
13(1), 19-28. DOI:

https://doi.org/10.29303/jbt.v13i1.68

Budiyani, N. K. \& Sukasana, I W. (2020). Pengendalian Serangan Hama Lalat Buah pada Intensitas Kerusakan Buah Cabai Rawit (Capsicum Frutescens L) dengan Bahan Petrogenol. AGRICA, 13(1), 15-27. DOI:

https://doi.org/10.37478/agr.v13i1.279

de Guzman, C.C., \& Siemonsma, J.S. (1999). Spices. Plant Resources of South-East Asia. Backhuys Publishers, Leiden.

Drew, R.A.I. \& Hancock. (1994). The Bactrocera dorsalis complex of fruit flies (Diptera; Tethritidae; Dacinae) in Asia. Bull. Entomol. Res. Supp. 2, 1-68.

Efendy T. A., Rani, R., \& Samad, S. (2010). Pengujian Beberapa Jenis Tanaman Sebagai Sumber Atraktan Lalat Buah (Bactrocera Spp.) (Diptera: Tephridae) pada Tanaman Cabai (Capsicum annum L.). Prosiding Seminar Nasional. Universitas Sriwijaya, Palembang. http://repository.unsri.ac.id/id/eprint/2546 $\underline{2}$

Giri, L.N. (2008). Potensi Anti Oksidan Daun Salam Kajian Intifo pada Tikus Hiperkolesterolemia dan Hiperglikemia. Bogor: Program Studi Biokimia Fakultas Matematika dan Ilmu Pengetahuan Alam Institut Pertanian Bogor. http://repository.ipb.ac.id/handle/1234567 $\underline{89 / 33408}$

Guenther, E. (1990). Minyak Atsiri Jilid 3. Jakarta: Universitas Indonesia.

Hasyim, A., Lukman, L., \& Setiawati, W. (2020). Teknologi Pengendalian Hama Lalat Buah. Jakarta: IAARD PRESS.

Herminanto, Nurtiati, \& Kristianti, D. M. (2010). Potensi Daun Sereh untuk Mengendalikan Hama Collosobruchus analisis F. pada Kedelai dalam Penyimpanan. Jurnal Agrivigor, $3(1), \quad 19$. https://web.archive.org/web/2018041803 3759id_http://journal.trunojoyo.ac.id/agr ovigor/article/viewFile/253/235

Huan, L., Yi, J., Dong, J. Z. \& Lei, W. (2018). Science direct invasion, expansion and control of Bactrocera dorsalis (Hendel) in China. Journal of Integrative Agriculture, 18(4), 1-11. DOI:10.1016/S2095$\underline{3119(18) 62015-5}$ 
Kardinan, A. (2003). Tanaman Pengendali Lalat Buah. Bogor: Agromedia Pustaka.

Ladja, M. G., Hindun, I., Sukarsono, Susetyarini, R. E., \& Setyawan, D. (2018). Pengendalian Lalat Buah (Bactrocera sp.) Secara Biologi Menggunakan Atraktan dan Warna pada Tanaman Jambu Biji (Psidium guajava). Prosiding Seminar Nasional IV. Universitas Muhammadiyah Malang. $\quad$ http://researchreport.umm.ac.id/index.php/psnpb/article/ view/2567

Lestari, A. P. A., Artayasa, I P., \& Sedijani, P. (2020). Ethanol Extract of Pseudo-stem Lemongrass (Cymbopogon citrates) and Basil Leaves (Ocimum sanctum) Increase Bactrocera (Diptera: Tephritidae) Fruit Fly Catches. Jurnal Biologi Tropis, 20(3), 369-377.

DOI: http://dx.doi.org/10.29303/jbt.v20i3.2070

Muryati, Hasyim, A. \& Kogel, W.J. (2007). Distribusi Lalat Buah di Sumatera Barat dan Riau. J. Hort, 1, 61-67. DOI: http://dx.doi.org/10.21082/jhort.v17 n1.2007.p\%25p

Plant Health Australia (2018). The Australian Handbook for the Identification of Fruit Flies. Version 3.1. Canberra, ACT: Plant Health Australia.

Saenong, M. S. (2016). Tumbuhan Indonesia Potensial Sebagai Insektisida Nabati untuk Mengendalikan Hama Kumbang Bubuk Jagung (Sitophilus spp.). Jurnal Litbang Pertanian, 35(3), 131-142. DOI: http://dx.doi.org/10.21082/jp3.v35n 3.2016.p131-142

Sari, D. E., Sunarti, Nilawati, Mutmainna, I., \& Yustisia, D. (2020). Identifikasi Hama Lalat Buah (Diptera: Tephiritidae) pada Beberapa Tanaman Hortikultura. Jurnal Agrominansia, $\quad 5(1), \quad$ 1-9. https://agrominansia.stipm-sinjai.ac.id

Simbolon, R. I., Indrayani, Y., \& Husni, H. (2015). Efektifitas Bioatraktan dari Lima Jenis Tanaman terhadap Rayap Tanah (Coptotermes sp). Jurnal Hutan Lestari, 4(1), 40-46.

DOI: http://dx.doi.org/10.26418/jhl.v4i1. 14482

Siregar, M. F., \& Sutikno, A. (2015). Identifikasi Lalat Buah (Bactrocera spp.) pada Tanaman Buah di Beberapa Kabupaten
Provinsi Riau. Jom Faperta, II (2). https://media.neliti.com/media/publicatio ns/201269-none.pdf

Siwi, S. S., Hidayat, P., \& Suputa. (2006). Taksonomi dan Bioekologi Lalat Buah Penting di Indonesia (Diptera: Tephritidae). Bogor: Balai Besar Penelitian dan Pengembangan Bioteknologi dan Sumberdaya Genetik Pertanian.

Sumono, A. \& Agustin, W., (2008). The Use of Bay Leaf (Eugenia polyantha Wight) in dentistry. Dent Jurnal, 41(3), 147-150. DOI:

http://dx.doi.org/10.20473/j.djmkg.v41.i3. p147-150

Susanto, A., Natawigena, W. D., Puspasari, L.T. \& Atami, N. I. N. (2018). Pengaruh Penambahan Beberapa Esens Buah pada Perangkap Metil Eugenol terhadap Ketertarikan Lalat Buah Bactrocera dorsalis Kompleks pada Pertanaman Mangga di Desa Pasirmuncang, Majalengka. Jurnal Perlindungan Tanaman Indonesia, 22(2), 150-159. DOI: https://doi.org/10.22146/jpti.27001

Wardani, S. (2009). Uji Aktivitas Minyak Atsiri Daun Batang Serai (Andrpgon nardus L.) Sebagai Obat Nyamuk Aedes aegypti. Skripsi. Universitas Muhammadiyah Surakarta.

White, I.M. \& Hancock, D.L. (1997). Cabikey to the Indo-Australian Dacini Fruit Flies [CD ROM]. Oxfordshire, UK: CABI Publishing. 